\title{
A dinâmica territorial brasileira e a inversão da "tese da fronteira" na porção sul do novo mundo ${ }^{1}$
}

\author{
César Ricardo Simoni Santos ${ }^{2}$
}

\begin{abstract}
RESUMO
A dinâmica territorial do avanço da fronteira é um dado na experiência das sociedades americanas pós-coloniais. A colonização européia, iniciada quase sempre pela borda leste do continente, consumiu, se apropriou e transformou progressivamente os territórios americanos de Leste para Oeste. Esse avanço, representado inicialmente pelo movimento de entrada dos povos colonizadores europeus, continuou como marca de uma sociedade que não conheceu os limites físicos de uma territorialidade restrita. No entanto, apesar da identidade que essa dinâmica confere aos territórios americanos, seus desdobramentos e causas posteriores parecem ter diferenciado bastante aqueles representantes do Norte daqueles do Sul. Assim também como a interpretação desses fatos vai assumir contornos e sentidos muito diferentes em cada uma dessas regiões.
\end{abstract}

Palavras-chave: Fronteira, território, identidade.

\begin{abstract}
It is a generally acknowledged fact that the dynamics of frontier advance deeply influenced the broad experience of American post colonial societies. The colonization, which started most from the east boundaries of the continent, appropriated and gradually transformed the American territories from east to west. The advance, initially represented by the arrival of the European settlers, went on to become an important trace of that society which did not come to know any physical limits of a restricted territory. However, despite the common identity granted by these territorial dynamics, the later developments and consequences seem to have shaped differently the Northern representatives from their Southern counterparts. In addition, the interpretation of these facts bore in each of these regions different meanings and traits.
\end{abstract}

Key words: Frontier, territory, identity.

O processo da reprodução capitalista na periferia ou no interior daqueles territórios colonizados por ação direta do expansionismo europeu assumiu uma dinâmica igualmente expansionista. A partir dos influxos externos, essa dinâmica internacional se replicou no interior dessas

1 Artículo recibido el 7 de octubre de 2009 y aceptado el 4 de enero de 2010. formações territoriais. O século XX é, também ele, testemunho dessa interiorização periférica de uma dinâmica global de reprodução capitalista. $\mathrm{O}$ avanço sobre novos territórios da acumulação marcou a dinâmica cartografia de uma reprodução inquieta da economia industrial.

\footnotetext{
2 Departamento de Geografia Humana, Universidade de São Paulo (Brasil). E-mail: cesarsimoni@usp.br
} 
No entanto, essa mesma dinâmica que parece apontar para uma identidade entre os processos de formação territorial que varreram as Américas atingiu resultados muito diversos, ao menos no que diz respeito às diferenças entre o norte e o sul. O fundamento da democracia radical que Frederick Jackson Turner pode observar na vida social e política dos Estados Unidos não deu origem, nos países localizados mais ao sul, ao mesmo teor democrático norte-americano reconhecido por ele. A pretensa constituição, a partir da "tese da fronteira", de uma matriz universal para a interpretação da realidade americana foi, por isso, frustrada. Podemos acompanhar, portanto, a partir de uma breve análise dos processos que estiveram envolvidos no avanço da fronteira de ocupação em território brasileiro e do debate intelectual que se seguiu na tentativa de interpretação desse fenômeno, os encontros e desencontros que se estabeleceram entre a teoria de Turner e o caso do Brasil. Funda-se aqui a necessidade de confronto entre a matriz de pensamento que estruturou uma reflexão sobre a constituição da identidade americana nos EUA, de pretensão claramente universalista, e a realidade e representação que o mesmo processo identificado por lá produziu por aqui. Nesses termos, estrutura-se o objetivo central do artigo que aqui se apresenta.

Este artigo se insere no conjunto de um estudo mais amplo sobre a importância da fronteira móvel para a definição dos aspectos mais particulares do padrão de crescimento da economia capitalista no Brasil. Aqui, no entanto, interessa mais os elementos particulares que caracterizam a dinâmica da fronteira no Brasil, e isso será alcançado a partir de uma análise comparativa. De forma muito geral, podemos considerar que o artigo traz a intenção de delinear com maior clareza os planos de identidade e as incompatibilidades estruturais que existem nas diversas interpretações do fenômeno da fronteira móvel entre as porções Norte e Sul do continente americano. Esse objetivo de ordem mais ampla, no entanto, só será contemplado, mesmo que parcialmente e de forma limitada, com a análise de objetos específicos. Com algumas considerações sobre a condição das terras livres no Brasil e algumas interpretações do fenômeno da fronteira por intelectuais brasileiros, pretende-se demonstrar a incompatibilidade substancial entre uma pretensa matriz universal -amplitude que se quis atribuir à teoria de Turner- e o caso sul-americano da dinâmica territorial de avanço da fronteira. A partir da evidência empírica e do tratamento dado ao fenômeno da fronteira móvel no Brasil, tem-se a pretensão de buscar algumas linhas de proximidade e de divergência entre Turner e o caso brasileiro. O espaço em questão e o ambiente intelectual analisado são, para isso, aqueles ainda muito ligados às dinâmicas da primeira metade do século XX. Nisso consiste a especificidade do texto que se segue.

Claro está que, as divergências e impossibilidades de compatibilização teórica que cercam a teoria de Turner para uma aplicação irrestrita ao caso brasileiro e, em geral, aos territórios da face atlântica da América do Sul devem ser postas em destaque. Mas, ao mesmo tempo, deve-se também reconhecer que não são por poucos motivos que muitas das idéias desse autor ecoam entre as mais sérias e comprometidas análises da realidade territorial brasileira.

\section{Expansionismo interno e identidade nacional: Turner e a história americana}

A busca por novos mercados e por novas oportunidades de realização de investimentos lucrativos, já no século XIX, estimulou o expansionismo industrial e financeiro que se originou na Grã Bretanha. Como já havia observado Lenin (1979), o avanço sobre a periferia garantia as condições de reprodução capitalista do capital industrial e financeiro originado no centro. Do ponto de vista da hegemonia britânica, entretanto, esse processo resultaria, sem escapatória, num tiro contra o próprio pé. A industrialização de outras regiões do globo acabaria, primeiramente, com a hegemonia industrial da economia inglesa e, num segundo momento, com a própria hegemonia financeira que sustentara até então o mecanismo autodestrutivo do poder exclusivo e concentrado daquela ilha (Harvey, 2004). Tudo isso, no entanto, não sem criar, ao mesmo tempo, os elementos para a busca 
de uma identidade própria a essa condição comum ao Novo Mundo.

De acordo com Giovanni Arrighi (1996), a expansão do capitalismo mundial prosseguiu, a partir do fim do século XIX, segundo um novo padrão territorialmente expansionista. Os Estados Unidos, na condição de novo centro da economia e do poder internacionais, se constituiria num "compacto 'império' territorial doméstico" (Arrighi, 1996: 60). Por isso, nas palavras de Gareth Stedman Jones, "toda história interna do imperialismo dos Estados Unidos foi um vasto processo de conquista e ocupação territorial" voltado, inicialmente, para o interior de seu próprio território, ao contrário daqueles modelos imperialistas mais evidentemente extrovertidos, como foi o caso da última fase de sua antecessora versão britânica (Arrighi, 1996). Desde o final do século XIX, os Estados Unidos se alimentaram recorrentemente desse movimento que permite, na falta de condições externas, um crescimento expansionista tipicamente introvertido. O arranque para a hegemonia norte-americana passa por essa mudança nos padrões territoriais e geopolíticos de reprodução do capitalismo.

Tal acontecimento não passaria desapercebido por uma consciência desejosa de uma ideologia que ancorasse sua prática. Por isso, o expansionismo interno norteamericano vai sustentar, em um de seus pilares, a formação do ideário nacional dos Estados Unidos e colocar entre as principais virtudes do homem branco americano o espírito desbravador e de colonização. A marcha para o Oeste funda, por isso, uma mitologia acerca do próprio "ser americano". Isso fez da vitória da civilização contra a rude natureza, percebida no avanço sobre os espaços ainda não desbravados pelo homem branco, a síntese ideológica que costura o ideal de nação nos Estados Unidos.

Frederick Jackson Turner inicia seus trabalhos de história econômica já no início da década de 1890. Nascido e formado em Wisconsin, Turner traria para o seu trabalho as fortes e mais atuais influências de seu tempo e de sua região. Wisconsin é, para ele, o resultado típico da expansão da fronteira americana, movimento esse que, para nós, será de grande importância para compreender as dinâmicas que se instauram a partir da crise da hegemonia britânica desde os fins do século XIX. Turner vai assistir a consolidação da economia industrial dos Estados Unidos e toda a dinâmica territorial de avanço que o processo assume. Por isso ele será um dos principais pensadores sobre o papel do avanço da fronteira na formação americana (Stadniky, 2007).

Turner ganha importância também como um dos primeiros a pensar o desenvolvimento dos Estados Unidos como resultado da combinação de fatores internos e, portanto, como singularidade definida pela situação política, econômica e geográfica encontradas em solo americano. Nesse sentido, a produção de Turner se reveste de positividade e a história dos Estados Unidos deixa de aparecer como mera extensão da história européia. O europeu, para ele, ao pisar em terras americanas, se transforma diante das condições encontradas no "novo continente"; ele é "americanizado" e abandona a sua antiga condição para se tornar o elemento que funda uma nova história e um novo território, descontínuos em relação aqueles que o colonizaram. É o sentido da "americanização" de elementos estrangeiros, ao contrário da tônica dominante até o momento, que apontava os EUA como resultado singular e positivo da incompleta transferência de valores do velho mundo (Wegner, 1998; Wegner, 1997). É nesse sentido que os aspectos distintivos da formação dos Estados Unidos, para Turner, estão definitivamente nos elementos que compõem uma sociedade e economia de fronteira. As "terras livres", o espírito de aventura do pioneiro, o isolamento dos povos estabelecidos nas zonas fronteiriças, a luta contra a rude natureza, o choque entre civilização e barbárie, a transformação que se opera no europeu, o caráter primitivo da fronteira etc. são os elementos que tornaram singular a formação americana, segundo essa visão. O processo de um movimento expansionista em direção ao Oeste primitivo seria então, a partir de certa recorrência, o elemento fundante do caráter americano ao reavivar essa condição na formação do território dos Estados Unidos (Turner, 1976). 
Em termos gerais, essa experiência, por si só, não é nova. Uma prática expansionista e a conclamação de um espírito desbravador podem ser buscados em territórios e períodos outros, anteriores a este que se refere ao período de formação territorial dos Estados Unidos. O espírito cruzadista e a expansão marítima que se inicia entre os séculos $X V$ e XVI antecipam a experiência fundante do ideal de nacionalidade dos Estados Unidos apontado por Turner. Mesmo o neocolonialismo dos séculos XIX e XX, por sua importância e magnitude, não devem ficar de fora do conjunto de experiências concorrentes. O que há de realmente inusitado na moderna história de formação dos Estados nacionais dos países do "novo mundo" é que a fronteira, nesses casos, não mais se fazia coincidir com os limites de um certo domínio territorial, ou sequer se projetava para além desses limites. Não só a expansão promovida durante a "marcha para o Oeste" inseria a experiência da fronteira na história da formação do ideário nacional norte-americano, como também trazia para o interior de seu próprio território a experiência que outras nações somente viveram na exploração de espaços situados para além dos limites de seus domínios diretos. A introjeção não coincidente da fronteira definida no interior dos limites territoriais parecia ser a condição distintiva dessa experiência moderna.

A possível confusão conceitual entre limites e fronteiras, que Lia Osório Machado (1998) procura desfazer, não é herança, definitivamente, da experiência de formação desses países que têm como identidade a condição de ex-colônias na América. A coincidência empírica entre os limites territoriais e a fronteira de ocupação, como fenômeno gerador de confusões conceituais, caracteriza com muito mais facilidade a realidade de países europeus.

Na Europa Ocidental, durante o declínio do feudalismo, entre os anos de 1250 e 1350, as fronteiras internas já haviam praticamente desaparecido. Por isso, o feudalismo, em sua fase de declínio, foi caracterizado, por Archibald Lewis e Ruggiero Romano, "pela limitação do estoque de terras ou pelo fechamento da fronteira", definindo "a impossibilidade do sistema feudal crescer em extensão (...)[ou] incorporando novas terras" (Silva, 2003: 09). A estabilidade, portanto, da situação das fronteiras de ocupação no interior da Europa Ocidental contrasta, de maneira inversa, com a realidade de limites territoriais ainda em disputa. No caso europeu, a definição dos limites territoriais parecia ser algo muito mais indefinido e sujeito a reajustes ocasionais do que a própria situação das fronteiras. Esse é o aspecto distintivo da situação americana. Em The Significance of the Frontier in American History $^{3}$, Frederick Jackson Turner escreve:

"No caso da maioria das nações, entretanto, o desenvolvimento ocorreu numa área restrita; e se a nação se expandiu, ela encontrou outros povos crescendo, os quais foram conquistados. Mas, no caso dos Estados Unidos, nós temos um fenômeno diferente. Limitando nossa atenção à Costa Atlântica, temos o fenômeno familiar da evolução das instituições numa determinada área... Mas temos também, além disso, a recorrência desse processo de evolução em cada área a oeste que foi atingida pelo processo de expansão. Desse modo, o desenvolvimento americano exibiu não somente o avanço ao longo de uma única linha, mas um retorno às condições primitivas no avanço contínuo da linha de fronteira, e um novo desenvolvimento para aquela área. O desenvolvimento social americano foi continuamente reiniciado na fronteira. Esse constante renascimento, essa fluidez da vida americana, essa expansão para o Oeste com essas novas oportunidades, esse contínuo encontro com a simplicidade da sociedade primitiva fornecem as forças que dominam o caráter americano" (Turner, 1976: 2-3).

\footnotetext{
3 Publicado pela primeira vez em 1893 e escrito para a American Historical Association, em Chicago, o ensaio entitulado The Significance of the Frontier in American History foi reeditado como o primeiro capítulo do livro The Frontier in American History (Turner, 1976), versão na qual é utilizado aqui.
} 
A razão da grande divulgação da tese de Turner e de sua igualmente memorável originalidade "foi, portanto, ter operado uma mudança de perspectiva no ponto de partida dos trabalhos de história econômica; em outros termos, a sugestão de que a história americana fosse recontada a partir da ocupação da fronteira, porque a marcha para o Oeste era o aspecto distintivo da sociedade que se formava mostrou-se fecunda" (Silva, 2003: 1). "Para Turner, a expansão da fronteira e o recuo da natureza virgem e da barbárie foram uma tentativa de criar um espaço habitável a partir de uma natureza hostil e não cooperativa. Isto compreendeu não apenas um processo de expansão espacial e a progressiva dominação do mundo físico" (Smith, 2007: 15).

\footnotetext{
"Enquanto os países europeus consolidaram Estados nacionais baseados na homogeneidade étnica e cultural dos seus integrantes, os países das Américas que emergiram da situação colonial se viram na contingência de forjar uma identidade singular para a sustentação ideológica da nação-Estado em formação. Na América do Norte, a ocupação dos 'espaços vazios' foi um dos momentos centrais deste processo não apenas porque integrou à economia mundial grandes áreas de terras férteis, mas porque o imaginário geográfico desta ocupação serviu de mito fundador da nacionalidade e elemento de racionalização da modernidade e do desenvolvimento capitalista" (Silva, 2003: 1).
}

Assim, para Turner, o desenvolvimento da fronteira "também foi a experiência central que definiu a singularidade da identidade nacional americana". Para ele, "em cada avanço do limite externo realizado por pioneiros robustos, não apenas novas terras eram acrescentadas, mas novo sangue era inserido nas veias do ideal democrático americano" (Smith, 2007: 15). A partir daí, no entanto, a tese de Turner se presta, ainda, a uma interpretação enviesada do expansionismo interno americano, que nem de longe poderia encontrar eco na realidade das Américas mais ao Sul. A tese de que a disponibilidade de "terras livres" tenha gerado a democracia social e política dos EUA não se aplica, evidentemente, à realidade das Américas espanhola e portuguesa.

\section{As "terras livres" ao sul do Equador e o negativo da "tese da fronteira" de Frederick Jackson Turner}

No Brasil, a abundância de terras não resultou, definitivamente, numa democrática distribuição fundiária ou dos direitos e poderes políticos. Isso porque essas terras consideradas abundantes somente o foram para os desserviços de uma classe dominante oligárquica. Primeiramente, a falta de uma ingerência mais ostensiva do poder central sobre essas terras, a partir da insuficiência dos sistemas legais reguladores da posse fundiária, foi acobertada pela total falta de liberdade do trabalhador numa sociedade escravocrata. Nesse período, que durou do fim da colônia até o ano de 1850, quando da primeira lei de terras do Brasil, a posse era livre; o trabalhador é quem não era. Esse sistema de compensação legal que se opera entre a regulação da posse da terra e a regimentação das condições de trabalho, foi responsável pela manutenção de um sistema fundiário extremamente concentrado.

Após recaírem sanções internacionais sobre o comércio sul-atlântico de mão-deobra escrava, como o Slave Trade Act (Lei Bill Aberdeen, de 1845), o Império do Brasil começa a se preparar, em 1850, para a adoção gradual do trabalho livre. No mesmo ano da aprovação da Lei Eusébio de Queirós, a primeira lei de terras entra em vigor. A instituição legal da propriedade privada da terra passa a ser, nesses termos, o instrumento regulador da posse e do uso do solo no Brasil. Em última instância, o acesso à terra, a partir daí, seria regulado por aqueles que detivessem os títulos de propriedade do solo, e estes somente poderiam ser obtidos, em condições correntes, mediante à compra e venda desses fragmentos do território. O trabalhador empobrecido, seus filhos, os imigrantes recém chegados, os escravos, ex-escravos e descendentes de escravos, em suma, toda essa crescente massa de trabalhadores não teria, por isso, a garantia do acesso a suas próprias condições e meios de trabalho. Continuariam, dessa forma, 
servindo, num outro regime de trabalho, mesmo depois de 1888, aos mesmos senhores a que serviam antes. Essa foi a condição para a manutenção de um vigoroso regime oligárquico descentrado e fundado no poder das elites regionais. Por essa razão, o acesso à terra deveria ser coibido por aqui, na América não-saxônica do Sul. E é por isso que, freqüentemente, "a 'abundância de terras' foi vista como um obstáculo a ser contornado" (Silva, 2003: 8).

Na Argentina, a partir da segunda metade do século XIX (e, mais especificamente, com a retirada de Rosas do poder, em 1853), inicia-se um "conflito permanente entre o setor de classe média (...) e o de proprietários de terras (...). Este último grupo foi o que influenciou a aprovação da Lei de Colonização de 1876, que pôs fim às esperanças de uma colonização de classe média no campo" (Lenz, 2006: 546). Assim, nota-se que o processo que demarca a participação dessas economias periféricas em expansão no complexo jogo do capitalismo mundial pressupõe, ao contrário do que previa o modelo clássico da transição para o capitalismo, uma derrota da burguesia local em face dos interesses de grandes proprietários fundiários que compõem o núcleo de uma classe pré-capitalista. Após as ações militares de "pacificação" do indígena e de tomada efetiva das terras sob domínio do Estado argentino, essa terra foi destinada a alguns poucos homens influentes na política e economia definidas por um regime dependente e agro-exportador.

"Cucoresse (...) questiona a ocupação da seguinte forma: $i^{\prime} Y$ que se pasó con la tierra conquistada? ¿Fue entregada para su lambranza a argentinos nativos y a los imigrantes? No resultó así. No se pobló el desierto. La tierra fue entregada en propriedad a pocas familias. La tierra ya había sido otorgada, aún antes de conquistada" (Lenz, 2006: 550-551).

As Campanhas do Deserto, como ficaram conhecidas as ações militares que tinham por objetivo a incorporação definitiva de territórios indígenas aos domínios do Estado argentino, liberaram frequentemente novas terras para a ocupação de uma atividade extensiva de exportação. O gado bovino foi, em muitos casos, o pioneiro da fronteira de ocupação argentina. "Povoar" o deserto foi, por isso, recorrentemente entendido (e de fato) como povoar com gado (Lenz, 2006). A propriedade da terra, também no território argentino, chegou antes da ocupação e do povoamento com gente.

O caso da Argentina apresenta similitudes em relação ao caso brasileiro, segundo a análise de Ligia Osório Silva (2003):

"Seja na visão paradigmática de Sarmiento que enxergava os 'espaços vazios' como local da barbárie, seja no Parlamento brasileiro, onde as discussões a propósito do primeiro projeto de lei de terras giraram com freqüência em torno das teorias de Wakefield sobre o preço da terra, a visão das terras da 'fronteira' como um manancial de riquezas, comum nos Estados Unidos, não caracterizou o discurso sobre a fronteira no período" (Silva, 2003: 8).

Isso revela um projeto claro, elaborado pelas elites locais ou em nome delas, que orienta o processo de ocupação territorial na América Latina. Esse não gera, em hipótese alguma, ao contrário daquilo que Turner havia descrito para o caso do avanço da fronteira nos Estados Unidos, a democracia social resultante da disponibilidade universal das terras não desbravadas. Por aqui, o acesso à terra manteve seu caráter distintivo e seletivo, preservando a concentração dos poderes, da riqueza e de um sistema político atrasado, segundo José de Sousa Martins (1999). "Em contraste com a política estadunidense de terras", as classes dominantes brasileiras, através disso, "apesar de toda a propaganda em favor da imigração e da pequena propriedade, praticaram uma política de terras que Ihes permitiu açambarcarem as terras públicas e fazerem da imigração não uma política de formação da 'nacionalidade', mas, em primeiro lugar, uma política de mão-de-obra" (Silva, 2003: 12).

Por aqui, em suma, desde o século XIX, "a legislação de terras que acompanhou o processo de ocupação da fronteira não foi eficaz no processo de implantação da pequena propriedade, acessível aos 
imigrantes recém chegados" ou ao filho da terra que crescia em número. "Em conseqüência não era possível que o mito da fronteira exercesse o mesmo papel que desempenhara nos Estados Unidos". Na Argentina do século XIX, nesse aspecto, como um caso similar ao do Brasil, encontramos "a experiência da fronteira gerando o inverso da tese turneriana, um mito negativo, na literatura acadêmica e na cultura popular. A fronteira foi vista como um lugar brutal, onde prevalecia a lei do mais forte e a justiça só poderia ser imposta de fora através da ação de representantes legais de instituições sediadas em centros urbanos distantes". Para Ligia Osório Silva, por isso, "a existência de grandes extensões de 'terras livres' (no sentido do século XIX) apareceu no imaginário argentino e brasileiro (...) como um 'peso' que as regiões do litoral precisavam carregar" (Silva, 2003: 12).

Se, portanto, é a negação da disponibilidade universal das terras que funciona como princípio da dominação territorial no Brasil, essas terras, do ponto de vista dessa mesma elite política, deveriam permanecer no interior dos negócios efetuados entre essas oligarquias. De acordo com Ariovaldo Umbelino de Oliveira (1996), 40 anos após a criação da lei de terras de 1850, a primeira constituição republicana repassava para as mãos dos governos estaduais a ingerência sobre as terras devolutas, e isso reaproximava as elites locais do controle sobre as terras em território nacional. Dessa forma, a terra, na sua mais nova modalidade no Brasil, se transformava em "moeda de troca" nas negociatas privadas de dirigentes locais.

A utilização das terras devolutas para firmar acordos que asseguravam vantagens privadas ou entre instâncias e seções do poder estatal não permaneceu restrita às relações internas estabelecidas entre as elites locais. Essa prática ganhou destaque quando também, derrotadas as forças centrífugas e liberalizantes, durante o processo de centralização do poder, o Estado central precisou recorrer ao apoio das elites regionais.

Com a crise do padrão ouro e com a ruptura da divisão internacional do trabalho, já entre os fins do século XIX e início do $X X$, a independência política e econômica de cada fração do território nacional, em face de suas relações diretas com o exterior, desaba. A crise econômica mundial foi, no Brasil, também o mote de uma crise política. Os princípios de uma versão muito particular do liberalismo que sustentava uma espécie de "pacto federativo de não intervenção" entre as oligarquias regionais, às vezes explícito sob a nomenclatura de "política dos governadores", vão à ruína, e com eles toda organização política aparentemente estável que mantinha essa incipiente unidade territorial (Fiori, 2003).

Evidentemente, uma organização política do território do tipo que vigorou até então, mesmo garantindo, de alguma forma, a unidade territorial nacional, "não podia gerar integração e, pior do que isso, essa estratégia reforçava a heterogeneidade, mas era indispensável para o desempenho econômico e político dos setores hegemônicos" (Fiori, 2003: 118-119). Falidas as expectativas de manutenção dos poderes locais em face da estruturação de celeiros econômicos regionais ancorados nas relações com o exterior, somente restava o recurso ao poder central e à busca de um crescimento econômico internalizado que sustentasse a pífia e crítica configuração territorial do poder no Brasil. Para José Luís Fiori (2003), é a elaboração do Estado desenvolvimentista que vai absorver todo o potencial crítico da heterogeneidade política e econômica do território nacional. A perspectiva de minimação dos efeitos negativos dos possíveis conflitos entre as diversas elites regionais e da manutenção da unidade territorial se constituiu na grande aposta de um crescimento econômico orquestrado pelo centro gestor da crise: o poder central. Intenção essa, muitas vezes declarada explicitamente, tendo em vista o amplo reconhecimento que o assunto mereceu por parte de setores das diversas elites regionais e de seus correligionários subalternos. É por isso que, para Antonio Carlos Robert Moraes (2000), "deve-se considerar também o papel desempenhado pela formação territorial na armação da vida política do país, com o realce das ideologias geográficas nos momentos de ruptura e crise institucional" (Moraes, 2000: 24). 
Para além, no entanto, de um argumento ideológico ou de uma retórica sedutora, a manutenção da unidade territorial se colocou como um problema desde o início da formação brasileira. A heterogeneidade política e econômica do território nacional sempre ameaçou efetivamente a sua unidade e isso frequentemente apareceu como um problema para as diversas frações do poder em escala nacional, principalmente para os setores hegemônicos da vez, e para o próprio poder central, independente da correlação de forças existente entre estes. O desvio ideológico pressuposto nesses casos reside na imposição das necessidades de um grupo restrito à todos aqueles reunidos em um mesmo espaço de influência: o território. É nesse sentido que "a prática das transformações pelo alto -tão recorrentes na história do Brasil- não raro buscou legitimação sustentando-se no argumento da necessidade de manutenção da integridade territorial" (Moraes, 2000: 24), que atendia, efetivamente, aos interesses de um seleto grupo dentre as elites locais. Mas é possível ler a questão territorial como motivadora de diversas alterações no jogo de forças que define a hegemonia política no Brasil. Para Fiori (2003), essa é a dinâmica fundante do Estado desenvolvimentista brasileiro, e foi somente com o estímulo ao crescimento econômico que esse Estado logrou com êxito, durante décadas, o grande feito da manutenção da unidade territorial.

Por tanto, para combater a crise institucional que se abatia em território nacional e ameaçava, sob os influxos de uma crise mundial, a própria unidade política territorial, o Estado central, carregando a bandeira do "desenvolvimento" econômico, passa a concentrar o poder antes difuso. Isso significava, no entanto, extrair parte do poder que repousava nas mãos de antigas oligarquias regionais ou mesmo de elites mais integradas ao moderno circuito da divisão internacional do trabalho. Para conseguir o apoio necessário e a aderência de alguns setores menos diretamente beneficiados nesse processo de concentração do poder, "a utilização do estoque de terras públicas como 'moeda de troca' no processo de centralização e construção do Estado" (Silva, 2003: 11), foi essencial. Sendo que:
"De modo diverso ao ocorrido nos países europeus, os processos de concentração e centralização do poder (...) ocorreu quando havia ainda grande disponibilidade de terras, passíveis de serem cedidas em troca de apoios políticos. A construção do Estado e a centralização do poder não estiveram associadas apenas ao desenvolvimento dos mecanismos de extração fiscal (pouco desenvolvidos). Ocorreram também com base na distribuição do monopólio da terra aos grupos que poderiam desafiar a autoridade do grupo hegemônico ou para sedimentar alianças. No período analisado, para os Estados argentino e brasileiro o obstáculo fundamental na trajetória da formação da nação era o perigo da fragmentação" (Silva, 2003: 10).

Mas esse esquema elaborado para angariar apoio político à grande empreitada do Estado brasileiro, já no início do século $X X$, não minimizou a dependência do poder central em relação às elites regionais. Muito pelo contrário. Tomando como exemplo a emancipação dos poderes fragmentários e o processo de centralização ocorrido em países da Europa, por lá o domínio das terras por súditos era completo a essa altura e a remuneração de serviços prestados ao Estado não mais se poderia dar com base na cessão de bens hereditários sem o empreendimento de novas conquistas. Isso, ao mesmo tempo em que obrigou, criou as condições para que o Estado efetuasse o pagamento por tais serviços em dinheiro, resultado da regularidade da arrecadação fiscal. O resultado foi, inequivocamente, o aumento da submissão e dependência permanente do súdito ao domínio do monarca, anulando assim as tendências desagregadoras do sistema.

No caso brasileiro, não só a preservação das condições que sustentaram a prática da utilização do "estoque de terras livres" nas negociações do poder conferiu às forças centrífugas a substância do poder e autonomia que fragilizava permanentemente o poder central, como também relegou para segundo plano a própria esfera monetária como termo de encerramento contratual. A fragilidade do poder central o obrigava 
o tempo inteiro a readquirir o apoio de setores oligárquicos ao mesmo tempo em que os abastecia com a sua própria fonte de poder, impondo simultaneamente uma tendência fragmentária e dispersa para a organização territorial. Tendo em vista esse processo internamente divergente que orienta o esforço de centralização, os termos normalmente legitimados nessa esfera de poder adquiriam pouca ou quase nenhuma estabilidade, sendo reelaborados a cada nova articulação que sustentava precariamente a legitimidade do poder central. A provisoriedade da situação política, a instabilidade jurídica, a precariedade contratual, as sobreposições constitucionais, a infinidade de leis aprovadas e descartadas, a variação cambial, a troca recorrente de moedas e instituições monetárias, são exemplos da subordinação de tais instituições em face de um poder central que se reconstitui a partir de novos arranjos frágeis de poderes difusos. Por isso, mesmo nos períodos de maior centralização do poder no Brasil, as instituições políticas eram pouco duradouras e sustentadas por princípios descartáveis. Toda essa dinâmica preserva a lógica do favor e do clientelismo político no centro das relações de poder em detrimento das relações formais. O único valor estável, por que fonte do poder, foi a terra, e essa mesma foi o termo de encerramento dos acordos, políticos inclusive. Trata-se de um padrão primitivo de reprodução política e econômica, entendido agora como avesso à lei do valor, e, mais tarde, como objetivamente crítico desse pressuposto social. Logo se vê que a democracia social ao estilo norte-americano apresentada por Turner não esteve presente no processo que marcou o avanço da fronteira em território brasileiro. Isso se justifica na compreensão de que a fronteira foi sempre mais que um "peso" para as expectativas cosmopolitas e modernizantes da borda continental da América Portuguesa. Ela representou a possibilidade de sustentação de um regime político em constante expansão, num processo constante de "fuga para frente", no sentido empregado por José Luis Fiori (2003), mas de conteúdo explicitamente territorial. Não produzindo, no entanto, o novo e distintivo da identidade nacional, mas reproduzindo o velho sistema hierárquico deixado pela colonização. O avanço da fronteira em território brasileiro não promoveu a ampla democracia e liberdade como condições para a implantação de instituições políticas e de uma economia veementemente modernas. O processo que originou e deu continuidade a essa dinâmica territorial, promoveu, por aqui, um território articulado com base numa política atrasada e sustentada pela violência da usurpação das terras. Nesse avanço da fronteira, o território é marcado por relações econômicas e de poder absolutamente primitivas, do ponto de vista da reprodução de uma sociedade capitalista, e testemunha o mecanismo concentrador pressuposto pela predominância de uma classe improdutiva e parasitária de proprietários rurais.

Temos, então, uma diferença importante entre os processos representados pelo avanço da fronteira no interior de cada unidade territorial. Se nos Estados Unidos, segundo Turner (e nesse aspecto podemos ficar com ele), o avanço da fronteira foi responsável pela ocupação moderna que daria origem à configuração capitalista do território, por aqui, a dinâmica similar promoveu seu oposto, deixando grande parte dos territórios mais ao sul na condição de verdadeiras reservas pré-capitalistas para futuros movimentos expansionistas do capital.

\section{A fronteira: caminhos e descaminhos na elaboração intelectual de uma identidade continental}

No que há de comum, no entanto, entre Brasil e Estados Unidos, a partir das interpretações correntes do processo, podemos elencar a situação da fronteira de ocupação no interior de seus territórios e as condições propícias, por isso, a elaborações mentais mitologizantes. O avanço sobre o desconhecido, representado no imaginário (estratégico e ideológico) como o avanço sobre o "vazio" constitui um material riquíssimo para o aparecimento de histórias de heróis e mitos fundadores. Histórias que trazem o contorno das epopéias marítimas e dos heróis navegantes que por aqui chegaram a atracar e reiniciar, em terra, suas mesmas aventuras vividas em alto mar. 
Nos dois casos, no plano da fantasia que alimentou o mito, no entanto, "a fronteira significava o retorno às 'condições primitivas'” (Silva, 2003: 2). Por isso, Turner "definiu a fronteira como 'o ponto de encontro entre a barbárie e a civilização'" (Smith, 2007: 16). Desse modo, o caráter frequentemente associado às "condições primitivas" estará sempre ao lado dessa fronteira, tornando oportuna a história de um povo desbravador e de ímpeto civilizatório.

Para Turner, foi a dinâmica configuração territorial dos Estados Unidos, que comporta uma fronteira que se move em direção às "terras livres" do Oeste, que originou o caráter singular do povo e das instituições americanas. Essa configuração reverteu e ressignificou em benefício próprio todo um sistema institucional importado com a colonização. Com essa compreensão, Turner (1976) encontra um novo ponto de partida para a contagem da história das instituições e do território dos Estados Unidos. Turner operou um deslocamento de perspectiva em relação ao que era frequentemente apresentado como as bases para o estudo da formação de seu país. A partir da "tese da fronteira" tornou-se possível pensar numa singularidade dos Estados Unidos que se estabelecia para além da colonização européia. A partir de Turner, os Estados Unidos figuraria na literatura acadêmica como portador de uma história própria e não mais como mera extensão incompleta de uma história do expansionismo europeu (Wegner, 1998).

A americanização dos valores e instituições européias, que deu origem ao sistema de valores e jurídico norteamericanos e consolidou a ocupação e, efetivamente, um território dos Estados Unidos, se operou somente em função e na própria fronteira, nitidamente por duas razões: o contato com as condições primitivas que expunha o material vindo da Europa às novas condições exigidas pela vida no novo continente e a situação de isolamento que reforçava essa singularidade. Isso se explica pelo fato de que, primeiramente, "na fronteira o ambiente é muito duro para o homem" que chega da Europa para colonizar as novas terras. Isso faz com que esse homem "aceite as condições oferecidas, ou pereça". Assim, o pioneiro americano, na visão de Turner, "pouco a pouco, transforma as terras selvagens, mas o resultado não é a velha Europa, nem simplesmente o desenvolvimento do embrião germânico". "O fato é que, aqui, o novo produto é [em função disso] americano" (Turner, 1976: 4).

Apresentada essa dinâmica aglutinadora das forças que darão origem a uma sociedade e instituições tipicamente americanas, Turner, em segundo lugar, reforça o papel do Grande Oeste na formação americana ao apontar para a falta de comunicação com a Costa Leste ou para a reduzida influência, seja dos povos Europeus ou mesmo das instituições reguladoras da vida americana, sobre estes novos espaços de colonização recente. Para Turner, "o isolamento da região acentuou aquelas tendências peculiarmentes americanas". Tanto "a necessidade de facilitação para os transportes em conexão com o Leste induziu importantes esquemas de benfeitorias internas", quanto a própria falta de comunicação sugeriu um desenvolvimento mais autônomo do Oeste (Turner, 1976). Desse modo, o isolamento e primitivismo do Oeste, como lugar dessa dinâmica interna de expansão da fronteira, contribuíram para a formação do caráter americano no processo de formação territorial dos Estados Unidos. Esse é o duplo elemento de positividade que pode alçar um processo de formação da identidade nacional dos Estados Unidos divulgado por Turner.

Apesar de Turner ter se dedicado a discriminar, mesmo que brevemente, as diversas frentes pioneiras, o pescador, o mercador, o mineiro, o criador de gado e o fazendeiro encontram, na condição de agentes da fronteira americana, uma identidade. O pioneiro da fronteira, nos escritos de Turner, tem em comum o fato de ter sido lançado numa empreitada contra a rude natureza das terras desconhecidas. Esse desbravador, a figura típica que resgata "a disposição universal dos americanos para emigrar na direção do Oeste selvagem", é a síntese do "poder de expansão que lhes é inerente, e que, por agitar continuamente todas as classes da sociedade, está constantemente conduzindo uma grande porção de toda a população aos extremos 
confins do Estado, a fim de ganhar espaço para o seu desenvolvimento". Segundo, ainda, as palavras de Grund, é a dinâmica manifesta na prática do pioneiro da fronteira que vai revelar o desejo fundante do ideal nacional do americano de fazer "ampliar seu domínio sobre a natureza inanimada" do Oeste não civilizado (Turner, 1976: 7).

Essa unidade entre os diversos agentes da fronteira americana consiste no embrutecimento do europeu civilizado diante das dificuldades encontradas no distanciamento dos hábitos e regiões caracterizados por um estilo de vida mais próximo ao do europeu. O distanciamento da "civilização" é a condição para o renascimento de um novo povo, o americano. As condições da fronteira apagam os traços bem polidos e lapidados da civilização européia, e, segundo Turner, obrigam a nova civilização se elaborar a partir do zero. Os caracteres de uma nova civilização renascem das cinzas do antigo colonizador, numa renarrativização de estilo hegeliano da história americana. Essa positividade encontrada na obra de Turner exige a negação, por meio da total aniquilação, do europeu no processo de formação americano. O espaço reconstruído na fronteira é americano e não mais o representante das instituições e mentalidades européias, já destruídas no interior dos territórios do novo mundo. Esse "bravo" da fronteira, na perspectiva de Turner, é o veículo da nova civilização no processo de ocupação e avanço sobre o território ao mesmo tempo em que engendra, nele mesmo, a síntese e o germe de um povo que nasce sob as novas condições impostas pelas terras colonizadas.

No Brasil, a mitologia do bandeirantismo desempenhou esse mesmo papel. A busca de um elemento que pudesse forjar uma identidade nacional, atribuindo prioridade a São Paulo, resultou, sob os cuidados do IHGSP4, na promoção da figura heróica do

\footnotetext{
4 O Instituto Histórico e Geográfico de São Paulo (IHGSP) contou com a colaboração de ilustres homens letrados, como Teodoro Sampaio (já membro da Comissão Geográfica e Geológica), Herman Von Ihering (do Museu Paulista) e o
}

bandeirante (Schwarcz, 1993). A projeção ilusória de um bravo destemido, nobre de espírito e de gestos, foi a base da promoção do bandeirantismo como símbolo do ímpeto desbravador do pioneiro paulista. Mesmo sendo o bandeirante, na maioria das vezes, um indivíduo canhestro, de higiene precária, rude no trato pessoal, servil aos poderes da coroa e, mais tarde, aos encantos das moedas metálicas. Assim, "o bandeirante fazia jus a uma imagem muito veiculada, que aliava o estado paulista em sua ascensão às principais qualidades desses românticos e destemidos desbravadores do sertão" (Schwarcz, 1993: 132-133). Para isso, "exalta-se a hierarquia e a impetuosidade e sublima-se a violência e as motivações menos nobres desses movimentos. Nos discursos historiográficos e geográficos, a conquista territorial foi expressa basicamente mediante esse personagem paradigmático, que tinha na própria mobilidade espacial expansiva o seu elemento caracterizador" (Moraes, 2000: 25). Para Antonio Carlos Robert Moraes, "o recuo do meridiano de Tordesilhas é comumente apresentado como um feito estimulador do orgulho nacional, logo como um elemento rico para a doutrinação patriótica. Toda a mitologização do bandeirante e do bandeirantismo bem atestam esse fato" (Moraes, 2000: 24-25).

Na Revista do Instituto Histórico e Geográfico de São Paulo (RIHGSP), nos anos entre 1895 e 1940, a ocorrência de artigos relacionados às temáticas da expansão territorial e da valorização da figura do bandeirante como signo do desbravamento

fluminense Euclides da Cunha (admitido como sócio em 1897) (Ferreira, 2002; Costa, 2001). A questão da formação territorial brasileira foi objeto de preocupação de Euclides da Cunha (1967) em alguns de seus textos, como em $\grave{A}$ Margem da História, no qual a porção territorial da Amazônia conta com o homem como elemento faltante, ou mesmo no prefácio do livro Inferno Verde, de Alberto Rangel (1924). Teodoro Sampaio, com um texto mais pragmático e propositivo, também elege a ocupação territorial como um tema central de seus trabalhos (Sampaio, 1890). Mesmo em seus estudos sobre o Tupi, como fica evidente em O Tupi na Geographia Nacional (Sampaio, 1901). A formação e ocupação do território nacional parecia ser o grande mote para a elaboração de uma identidade para esse país periférico. 
é significativa. 12\% dos artigos estão ligados à temática do aparecimento, crescimento e tipologia das "Cidades e dioceses", 9,3\% à temática do "Povoamento e expansão bandeirante", 3,8\% aos "Descobrimentos e colonização", 1,8\% "Vias e comunicação" e $1,1 \%$ às "Narrativas de viagens e expedições científicas", segundo dados fornecidos pela própria RIHGSP, v. I-XXXIX (Ferreira, 2002: 126). "No rol dos trabalhos geo-históricos (...) os principais temas abordados são os caminhos coloniais, a navegação fluvial em direção às minas e as ferrovias paulistas com destino às regiões fronteiriças em época mais recente" (Ferreira, 2002: 134). Entre esses, com menor ocorrência, ainda, alguns artigos "aventuram-se na sondagem dos caminhos e veículos aéreos" (Ferreira, 2002: 134).

"Nos anos 10 e 20 [do século XX], principalmente, ganhou impulso o tema do bandeirantismo, estimulando a releitura dos cronistas dos séculos anteriores e a recolha de todo um material documental: manuscritos, mapas e roteiros de deslocamentos, inventários etc. Reaviva-se um período de aventuras e um espírito coletivo intrépido, considerando-se os bandeirantes como artífices do progresso regional, que continuava na cafeicultura, nas locomotivas, na metropolização da capital e nas indústrias. A atividade bandeirante era assim tomada como veículo da formação territorial paulista e da própria edificação do país" (Ferreira, 2002: 132-133).

Toda essa exaltação da imagem do bandeirantismo ocorre, no entanto, num contexto de disputa regional pelo mito fundador da identidade nacional. Essa disputa se dava na representação dos diversos institutos regionais, situado entre eles o próprio IHGB, que, apesar de carregar no nome a intenção declarada de ser representante supremo da nação, mantinha sede permanente no Rio de Janeiro e representava os interesses da elite carioca, aparecendo, portanto, como um instituto aliado aos interesses regionais do Rio de Janeiro (SCHWARCZ, 1993). O conflito entre Rio e São Paulo não resumia a diversidade de perspectivas postas em disputa no cenário nacional. Tais disputas "estendiam-se pelo país, tornando visíveis os regionalismos do final do Império e da Velha República, aflorando em diferentes expressões, institucionais ou simbólicas. Os institutos históricos estaduais, surgidos desde essa época, representariam bem esse clima de concorrência" (Ferreira, 2002: 109).

O Instituto Arqueológico e Geográfico Pernambucano (IAGP) entrou na disputa lançando mão da mitologização da ação do povo pernambucano contra a invasão holandesa. Nos trinta primeiros números da Revista do IAGP (RIAGP), entre os anos de 1863 e 1930, 51\% dos artigos remetiam-se diretamente à temática da invasão holandesa (Schwarcz, 1993: 120). Assim como os demais institutos estaduais, o IAGP se consagra como um centro de produção e irradiação de um conhecimento servil às elites locais. No entanto, e por isso mesmo, o Instituto Pernambucano era o representante dos anseios de uma elite decadente, "e que, em face da insegurança da nova situação econômica, 'desejava através de seus romantismos culturais preservar o passado como um escudo contra o futuro'" (Schwarcz, 1993: 118). Nesse sentido, o IAGP consolidou uma prática na produção do conhecimento correlata ao fenômeno segundo o qual "para a sociedade nordestina, a vida do senhor rural representava o pináculo da história" (Schwarcz, 1993: 123). Por isso, a mitologização desejada por Pernambuco não pôde se projetar na escala do território nacional. Nesse momento era a realidade da expansão urbana, com a simultânea formação de uma complexa rede de cidades, que se alastra pelo território. Esse processo, interconectado pela ferrovia, se irradia a partir de um centro: São Paulo. E é essa a dinâmica que exigiria, a partir daqui, um mito fundador -e não mais a antiga sociedade agrária, assentada no latifúndio canavieiro do Nordeste. O IHGSP, amparado por essa potente e dinâmica realidade que se irradia na direção da tomada de todo o território nacional e ganha impulso a partir de São Paulo, vai firmar o mito do bandeirante como a figura chave da conquista e tomada da terra.

Apesar de reconhecer a imagem heróica do bandeirante como um elemento forjado e estimulador de uma identidade nacional, 
Moraes (2000) não questiona o papel do movimento expansionista que empurra o avanço da fronteira em território nacional como um dado da formação da identidade nacional. $O$ autor entende que, no caso do recurso à exaltação do bandeirantismo, "o processo de apropriação do espaço exprime-se num tipo social específico - o bandeirante - ao qual corresponderia um tipo de organização social também peculiar: a bandeira, síntese da motivação expansionista fundante do Brasil" (Moraes, 2000: 25). Não sem conseqüências, ele entende, no entanto, que essa torção ideal se trata simplesmente de uma "transposição, do processo ao tipo" (Moraes, 2000: 25). Assim como Turner pensou para o caso da formação dos Estados Unidos, Moraes entende que:

"O imperativo da apropriação constante e extensiva do solo pode mesmo ser considerado um dos fios condutores da formação brasileira. Desde os primórdios, o próprio 'sentido da colonização' aqui estabelecido repousou em certas aptidões do território apropriado: afinal, de início, são condições ambientais distintas da metrópole que permitem a realização de explorações complementares. E a colonização do Brasil implicou a integral montagem dessas estruturas de produção, num movimento que sincronizou o povoamento, a apropriação do solo e a exploração produtiva propriamente dita. Em outros termos, tratou-se de um processo simultâneo de construção de uma sociedade e de um território, de uma sociedade que tinha na construção do território forte elemento de identidade" (Moraes, 2000: 24).

Importantes e respeitados pensadores da realidade brasileira se dispuseram a interpretar o processo de ocupação e formação territorial do Brasil desse mesmo ponto de vista. Numa referência de aula, no dia 7 de março de 2002, a professora Maria Célia Paoli, do departamento de sociologia da USP, versava sobre a importância de Gilberto Freyre para a formação de um pensamento positivo a respeito das instituições brasileiras. É a partir da consolidação desse novo posicionamento intelectual de nossos autores, de acordo com a professora, que se rompe, no Brasil, com a circularidade acética de uma espécie de "sociologia da falta", segundo a qual a realidade européia servia como o metro da evolução da sociedade brasileira. Isso significa, o que explica em grande medida o termo utilizado para classificá-la, que a sociologia brasileira esteve, até bem próximo da metade do século XX, refém de um vício teórico que frequentemente interpretava a realidade brasileira como uma realidade carente de elementos encontrados no centro da cultura ocidental. Retratada como capenga e incompleta, a formação brasileira, segundo essa, assim chamada, "sociologia da falta", deveria se espelhar nos países que a originaram. Por isso, os elementos da identidade nacional sempre foram encontrados num processo negativo que tem por base a realidade européia. Para os autores dessa linhagem, a especificidade nacional consistia na falta de alguns elementos que eram encontrados em civilizações entendidas como plenamente bem constituídas, como, por exemplo, aquelas detentoras de alguns hábitos e estruturas institucionais faltantes por aqui. Por isso, recorrendo a uma formulação de Otília Arantes (1998), em país de formação tardia e economia periférica "o moderno é uma obsessão nacional, entendido via de regra como esforço de atualização, sendo o metro a evolução das sociedades centrais" (Arantes, 1998: 37).

É claro que os autores dos institutos já vinham confirmando a tendência de abandono dessa perspectiva da "falta" desde a virada do século. Uma leitura sobre a orientação geral dos trabalhos revela um ponto de vista mesclado, no qual o aspecto incompleto da formação social, institucional, política ou econômica aparece atrelado a uma positividade da potência nacional. Essa potência, no entanto, para esses autores, somente abandonaria seu estado de letargia a partir da condução pela mão forte do Estado. É por isso que "a ensaística desses intelectuais, [como a de] Silvio Romero, Euclides da Cunha, Alberto Torres e Oliveira Vianna, entre tantos outros, de caráter eminentemente público, está orientada para a obra de conclusão do Estado nacional" (Vianna, 1996: 181). É assim que, para eles, "sobreposto, como ente moderno e racional, a uma sociedade que, além de 
intrinsecamente atrasada, seria marcada pela fragmentação e ameaçada por forças centrífugas regionais, ele [o Estado] visa exercer uma tutela pedagógica sobre ela, impondo, pela 'engenharia social', uma configuração orgânica ao que antes era disperso e invertebrado" (Vianna, 1996: 184). A elaboração da necessidade do Estado para por em funcionamento os elementos distintivos da nacionalidade era tal que, "para [Oliveira] Vianna, que apontava as debilidades e a ausência de uma sociedade liberal, o liberalismo somente poderia ser alçado na presença de um Estado forte, que pudesse romper com os elos da sociedade familiar, dominante em nosso meio" (Silva, 1999: 201).

Se, por um lado, Oliveira Vianna (1996) aponta para as debilidades da formação nacional assumindo como referência a história institucional européia, por outro, ele encontra na negação dessas instituições originárias o caráter distintivo da sociedade que se forma por aqui, assim como Turner havia compreendido o processo de formação singular do território dos Estados Unidos. A forte influência de autores que fundamentaram os trabalhos de sociologia positiva, como Emíle Durkheim, Augusto Commte, Buckle, Gobineau e Lapouge, definiu o rumo de muitos estudos e levantamentos sobre a situação brasileira, inclusive os de Oliveira Vianna. O elemento de positividade característico da formação brasileira seria encontrado, por Oliveira Vianna, na vida rural, nos sertões como domínio antagônico ao cosmopolitismo da vida nas regiões litorâneas. Socialmente, portanto, o "clã rural" de Oliveira Vianna se opunha à integração aos modos europeus que se estabeleceram na costa leste do continente. Essa forma de organização comunitária se elabora como manifestação genuína, fruto do território, por duas razões elementares que podem ser encontradas na situação de fronteira. Primeiramente, "em meio a uma situação absolutamente impar, as características do meio condicionaram e propiciaram uma formação social e psicológica realmente distintas" (Silva, 1999: 200). Em segundo lugar, "segundo Vianna, foi no isolamento solitário daquelas populações interioranas do centro sul, separada da costa pela muralha atlântica e, portanto, livres das vicissitudes e dos controles da coroa e longe das constantes ameaças dos espanhóis, que exigiam das populações sulinas a constante mobilização e objeção à presença do Estado, que se organizou uma sociedade baseada no clã rural" (Silva, 1999: 200). Foi essa condição de insularidade que garantiu aos "matutos paulistas" sua condição original no processo de formação do território brasileiro, diferentemente do gaúcho ou do sertanejo. Em síntese, "essa nova ordem era específica e surgira das condições do regionalismo econômico e da distância e debilidade da autoridade política central" 5 (Silva, 1999: 200).

Dois pólos tencionam, portanto, o processo de formação nacional na visão de Oliveira Vianna. Com um dos olhos voltados às instituições européias e outro para o agrarismo brasileiro, Vianna encontra o aspecto singular de nossa formação na relação entre o campo, o clã rural, e a vida urbana das cidades litorâneas. Há, portanto, aqui uma dicotomia fundante da realidade brasileira. O atraso, representado pelas relações de compadrio, pela política clientelista e por uma economia não exatamente capitalista, convive, numa relação de complementaridade, com a modernidade que se espelha nas metrópoles do centro econômico e cultural do século XIX. Oliveira Vianna, desse modo, antecipa uma potente chave de interpretação dos processos que engendraram o crescimento econômico em território nacional. Dois espaços de formações distintas e com vocações dissonantes, revelam-se complementares na articulação de um padrão de reprodução absolutamente híbrido e que encontra nessa condição a sua singularidade e posicionamento na reprodução econômica mundial. Essa diferença ganha seus contornos, para Oliveira Vianna, na relação entre os espaços de formação não-capitalista e aqueles de vocação mais declaradamente capitalista, associados às modernas condições de vida que se desenvolveram no centro.

\footnotetext{
5 Ênfase adicionada.
} 
"Ao contrapor os elementos da vida rural, seus ajustes e caracteres, à modernidade da vida urbana que, no Brasil, limitouse à faixa litorânea, voltada para o mundo europeu e suas metrópoles, Vianna o fez vinculando dois aspectos importantes dessa formação, que se traduzem justamente pela dicotomia entre o que poderíamos distinguir como sendo a relação entre os elementos précapitalistas e os elementos capitalistas que tencionaram essa formação" (Silva, 1999: 201).

Apesar da similitude com a "Tese da Fronteira", os aspectos primitivos presentes na fronteira em Oliveira Vianna não engendraram o mesmo espírito democrático presente na tese de Turner6. Elas são, até mesmo, "divergentes quanto às possibilidades concretas do surgimento e do desenvolvimento do espírito democrático" (Silva, 1999: 201). Para Henrique Manuel Silva:

“(...) Justamente nas profundezas do mundo rural, onde a definição de fronteira concretiza sua real substância, é que tanto Vianna como Turner encontraram seus argumentos para suas respectivas teses. Foi essa substância que para um engendrou o

6 Henrique Manuel Silva (1999), em A Temática da Fronteira na Historiografia Brasileira, diferencia o significado do mundo rural na produção de Turner e Oliveira Vianna. Segundo ele, "o mundo rural aparece preponderante como marca definidora do caráter nacional em Turner, tipificado na figura do colonizador pioneiro, desvinculado sobretudo dos aspectos da vida e das normas citadinas, e também caracterizado por uma profunda relutância a quaisquer formas de normatizações estatais. No caso de Oliveira Vianna, essa perspectiva ruralizante traduzir-se-á pela perpetuação dos valores nobiliárquicos da aristocracia na medida em que ela se interioriza mais e mais. O domínio da propriedade rural, desde os primórdios de nossa colonização portuguesa, prezou sempre pela opulência de seus solares e sedes. O proprietário, herdeiro muitas vezes, segundo Vianna, de uma tradição aristocrática lusitana e ibérica, tendeu a perpetuar a natureza de sua nobliarquia, ao longo de sua hereditariedade. Encontramo-nos, assim, diante de duas abordagens distintas acerca do meio rural (lê-se também mundo da fronteira), de naturezas diversas, uma de sentido transformador outra de natureza conservativa" (Silva, 1999: 201-202). republicanismo oligárquico e para outro determinou a radicalidade da democracia individualista" (Silva, 1999: 201).

No entanto, para Oliveira Vianna, o conservadorismo resultante da configuração classista e das relações sociais de produção tipicamente encontradas nos espaços rurais da fronteira de expansão em território brasileiro não é visto com "sinal positivo" (Wegner, 1997: 4), para usar uma expressão de Robert Wegner. Isso decorre do fato, já apontado, de que as instituições dos países centrais exerciam forte influência no imaginário formativo nacional. A referência externa serve, aqui também, como o parâmetro de avaliação de nossas próprias instituições. "Para Vianna, contrariamente ao que se observou na América, a perpetuação dos signos de nosso ruralismo constitui um obstáculo concreto à edificação da democracia" (Silva, 1999: 202). Dessa forma, o elemento distintivo da formação brasileira reaparece com "sinal negativo". É nesse sentido que é só parcialmente que Oliveira Vianna rompe com os mecanismos de uma certa sociologia da falta.

A tradição se estendeu no tempo. "Roland Corbisier costumava dizer que antes do movimento modernista o que tínhamos no Brasil era simplesmente pré-história. A afirmação, de inspiração hegeliana, mostra como os intelectuais dos anos 50 estabeleciam sua filiação a uma corrente de pensamento distinta daquela representada por Silvio Romero ou Gilberto Freyre" (Ortiz, 1985: 45). No entanto,

"Ao empreender uma busca da nossa formação ou do momento fundamental de construção da sociedade brasileira, a partir do processo de colonização, atendo-se ao estudo da tradição rural, do latifúndio e do ruralismo ou agrarismo para, enfim, chegar ao espírito ou à essência précapitalista ou cordial do nosso traço sociocultural, Vianna mergulhou nas vastidões das fronteiras interioranas, como o fez posteriormente Sérgio Buarque, embora este o tenha feito de maneira mais completa" (Silva, 1999: 200).

E é por isso que a nova concepção a respeito das instituições brasileiras se 
consolidaria somente com Sérgio Buarque de Holanda. Segundo Robert Wegner, a positividade da análise de Sergio Buarque de Holanda, que coloca acento no caráter distintivo da produção desse autor, aparece num contexto de aproximação com a realidade apresentada por Frederick Jackson Turner.

Para Richard Morse, os estudos sobre o continente americano podem ser divididos em dois grandes blocos organizados segundo os enfoques "genéticos" e "situacionais". Segundo esse autor, o enfoque genético valoriza mais a influência do europeu na formação do continente, sendo este considerado uma extensão da sociedade e instituições de ultramar. O enfoque genético valoriza o processo de formação nacional na América a partir do reconhecimento dos elementos de origem européia por aqui presentes. Para Richard Wegner, esse enfoque é aquele que predominou até a formulação da tese da fronteira de Frederick Jackson Turner (Wegner, 1998). O enfoque situacional, por sua vez, ganha espaço no debate de formação nacional dos países do continente americano a partir do século $X X$. Ele consiste no reconhecimento de fatores propriamente americanos forjados no contexto da colonização dos territórios do novo mundo. Esse enfoque "procura alguma dinâmica própria ao novo Continente que possa significar a impressão de uma marca particular nos valores do Velho Mundo para ele transportados. A dinâmica pode variar, mas em todo o caso podemos chamá-la de americanização" (Wegner, 1998: 2).

A diferença entre o enfoque "genético", adotado em Raízes do Brasil, e o enfoque "situacional", que ressalta os elementos constituintes e formativos próprios da singularidade resultante da ocupação do território americano, presente tanto em Monções quanto em Caminhos e Fronteiras, conta com um período de imersão do autor nos debates realizados em solo norteamericano. Em Sérgio Buarque de Holanda, a transformação de perspectiva que se opera entre o enfoque genético e o situacional se dá num momento em que o intercâmbio intelectual entre os países americanos se intensifica em função da política de boa vizinhança encampada por Roosevelt. Os "brasilianistas" surgem nesse momento e Sérgio Buarque de Holanda faz parte do seleto grupo ao qual coube, pelo menos por um período, o desafio de se pensar uma história comum das Américas. Apesar, no entanto, de todo o clima favorável a uma reflexão unitária sobre as particularidades do continente, "nenhuma chave explicativa do tipo situacional obteve um mínimo de consenso e sucesso para ser aplicada ao estudo do Continente. Uma tese bastante conhecida e que poderia, talvez, ter fornecido essa chave aos estudiosos do Novo Mundo era a tese da fronteira, de Frederck Jackson Turner" (Wegner, 1998: 4). Mas, também, "a tese de Turner não preenchia o requisito de ser aplicável a todo o Continente" (Wegner, 1998: 5). Contudo, diante de toda essa reviravolta no cenário intelectual internacional das Américas, um fator pareceu ser de grande importância ao nosso intelectual. "Sem se preocupar propriamente com a história de todo o Continente, Sérgio Buarque de Holanda (...) alerta para uma situação comum ao Brasil e aos Estados Unidos: a experiência da fronteira tal como definida por Turner" (Wegner, 1998: 6).

Richard Wegner recupera o trecho de uma palestra proferida na Escola Superior de Guerra no qual Sérgio Buarque manifesta o descontentamento com a perspectiva genética apresentada em Raízes do Brasil. Nas palavras de Sérgio Buarque:

“(...) no capítulo inicial (...) tratara eu do que julgara típico de certa 'mentalidade ibérica', cuja herança preservaríamos, e que nunca deixara naturalizar-se entre povos hispânicos o apreço moderno a atividade utilitária: entre esses povos como entre os da antiguidade clássica, importaria antes o ócio do que o negócio. Mais tarde procurei, de passagem, atenuar a formulação" (Wegner, 1998: 3).

Envolvido por todos os lados na matriz de um pensamento positivo ou situacional, como o próprio título do artigo já sinaliza, em Considerações sobre o Americanismo, Sergio declara a proximidade que acabou por estabelecer com o pensamento de Turner. Flertando ainda com um pensamento sobre o continente, tendo assumido um 
posicionamento mais claro ao lado de um pensamento situacional, para ele,

"em nosso continente, não obstante todas as diversidades étnicas e culturais, existem de norte a sul feições sociais com raízes idênticas, geradas da aplicação de velhas instituições e velhas idéias a uma terra nova e livre. Nesse sentido, podese mesmo dizer que, como o Oeste do historiador Frederick Jackson Turner, a América é antes uma forma de sociedade do que uma área geográfica" (Wegner, 1998: 7).

Essa será a matriz de interpretação da história brasileira, o ponto de vista situacional, de Sérgio Buarque de Holanda após a primeira metade da década de 1940, quando retorna dos Estados Unidos. A valorização dessa "dinâmica com sinal positivo" encontrou lugar no reconhecimento do fenômeno da fronteira também em Sérgio Buarque. "Dessa maneira, uma possibilidade explicativa que pareceu desinteressante à maioria dos historiadores das Américas é considerada instigante por Sérgio Buarque. Tal postura o leva aos bandeirantes e à conquista do

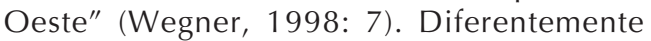
dos propósitos envolvidos no contexto da disputa entre o IHGSP e o IHGB, Sérgio preserva a figura típica do bandeirante como um elemento chave para a interpretação da história brasileira. É por isso que, em Sérgio Buarque, o bandeirante e o pioneiro da fronteira de maneira geral vão aparecer mais próximos da figura de um indivíduo rude e prosaico, distanciado da aura glamorosa que reveste a figura heróica pintada pelo IHGSP do início do século. Isso se justifica também pelo significado da fronteira na obra de Sérgio Buarque de Holanda. Se aqui também ela é o elemento transformador dos fatores estranhos à terra e o lugar de afirmação e nascimento de uma ordem singular, a fronteira modela o homem que se situa em seu interior. Em Sérgio Buarque, assim como em Turner, é o contato com os elementos primitivos e inesperados instalados para além da linha de fronteira que funda o novo homem americano, na mesma medida em que esse mesmo homem constrói o seu território. Em Monções (Holanda, 1990), as ricas e detalhadas descrições das técnicas que nascem em território americano, fruto das dificuldades apresentadas pelas áreas inexploradas e do contato com o nativo da terra, apresentam os elementos constituintes de uma nova sociedade nascente. Assim como a utilização desses novos objetos promovem a fixação e expansão dessa sociedade, eles favorecem também a apropriação dessas novas terras e o desenvolvimento de atividades inéditas que resultam do contato do europeu com as solicitações particulares do terreno. Em Caminhos e Fronteiras (Holanda, 1994), as relações de troca e o estabelecimento de novos lugares que atendem a essa atividade articulam no território uma formação social específica e internamente definida, de comportamento inequivocamente expansivo.

Sérgio Buarque, a partir da década de 1940, elege a temática da fronteira como um dos elementos centrais para a interpretação do Brasil. A importância desse elemento para a compreensão da dinâmica da formação territorial brasileira aparece nitidamente na introdução de Caminhos e Fronteiras. A mobilidade dos paulistas, mesmo sendo apontada como conseqüência da pobreza de situação na antiga Capitania de Martim Afonso, é considerada fator da singularidade dessa sociedade que se expandirá sobre o território. Nessas terras, qualquer movimento que impulsiona o colono ou o pioneiro o faz na expansão da fronteira oeste, distanciando este homem dos centros urbanos de estabelecimento antigo e, consequentemente, da realidade européia que adentra no continente pela borda Leste. Assim, tal mobilidade revela inequivocamente o caráter expansionista que lança seus pioneiros numa marcha incansável em direção ao Oeste do território sul-americano. Desse modo, ao referir-se ao povo paulista, Sérgio Buarque ressalta que "sua vocação estaria no caminho, que convida ao movimento; não na grande propriedade rural que forma indivíduos sedentários" (Holanda, 1994: 9). Foi dessa forma que Sérgio Buarque de Holanda "foi buscar nas vastidões interioranas e nas gentes paulistas o sentido de nossa formação, cuja fronteira em movimento se converteu no seu leitmotiv, difundindo-se e disseminando-se como um traço sui generis" (Silva, 1999: 205). 
Assim como Turner, Vianna, Sampaio, Euclides da Cunha e outros que elegeram a temática da fronteira para ocupar o centro da interpretação sobre a formação sócioespacial americana, Sérgio Buarque valorizou o primitivismo e o isolamento inovadores da situação de fronteira como fatores fundantes para uma análise positiva da formação brasileira. Assim, para ele,

"A lentidão com que no planalto paulista vão se impor costumes, técnicas ou tradições vindos da metrópole -é sabido como em São Paulo a própria língua portuguesa só suplantou inteiramente a geral, da terra, durante o século XVIII- terá profundas conseqüências. Desenvolvendo-se com mais liberdade e abandono do que em outras capitanias, a ação colonizadora realiza-se, aqui, por uma contínua adaptação a condições específicas do meio americano. Por isso mesmo não se enrija logo em formas inflexíveis. Retrocede, ao contrário, a padrões primitivos e rudes: espécie de tributo pago para um melhor conhecimento e para a posse final da terra. Só aos poucos, embora com extraordinária consistência, consegue o europeu implantar num país estranho algumas formas de vida que trazia do Velho Mundo. Com a consistência do couro, não a do ferro ou do bronze, dobrando-se, ajustando-se, amoldando-se a todas as asperezas do meio" (Holanda, 1994: 10).

Em outros aspectos também Sérgio Buarque de Holanda parece se aproximar e se orientar pelos trabalhos já clássicos de Frederick Jackson Turner. Distinguindo, "na própria fronteira, a fronteira do mercador, a fronteira dos lavradores, a fronteira do mineiro e a fronteira do fazendeiro" (Turner, 1976: 12), Frederik Jackson Turner reconstituía a partir da matéria sólida oferecida pela configuração territorial americana a sucessão dos eventos formativos daquela nova sociedade. A dinâmica dessa sucessão foi apresentada pela evolução ou avanço da fronteira. Segundo Turner,

"A fronteira atlântica foi composta pelo pescador, pelos mercadores de peles, pelo mineiro, pelo vaqueiro e pelo fazendeiro. Excetuando o pescador, cada tipo de empreendimento esteve na marcha para o Oeste, impelido por uma atração irresistível. Cada qual passou, em sucessivas ondas, sobre todo o continente. Posicionado no desfiladeiro de Cumberland e assistindo a procissão da civilização, marchando em fila -o búfalo seguindo o caminho do sal, o Índio, o mercador e o caçador, o vaqueiro, o lavrador pioneiro-, a fronteira passou. Posicionado no South Pass, nas Rochosas, um século mais tarde, vejo a mesma procissão com intervalos maiores entre si. Os ritmos desiguais do avanço nos compele a distinguir, na fronteira, a fronteira do mercador, a fronteira dos lavradores, a fronteira do mineiro e a fronteira do fazendeiro" (Turner, 1976: 12).

De certa forma, essa estratigrafia da formação social, econômica e política do território aparece também no olhar cuidadoso de Sérgio Buarque de Holanda. As camadas da história, também por aqui, a partir de alguns textos de Sérgio Buarque, aparecem cristalizadas nos diferentes estágios da fronteira ou, melhor dizendo, nas diferentes fronteiras que promoveram o efetivo processo de colonização do território. Em 1949, nos anais do Museu Paulista, Sérgio Buarque publica um ensaio entitulado Índios e Mamelucos na Expansão Paulista. Nesse ensaio, para apresentar a sucessão dos fenômenos que se enredaram no processo de formação do território brasileiro, Sérgio Buarque de Holanda apresenta o tropeiro como "o sucessor direto do sertanista e o precursor, em muitos pontos, do grande fazendeiro. A transição faz-se assim sem violência" (Wegner, 1998: 11).

No entanto, para Turner, a dinâmica do avanço da fronteira nos Estados Unidos conta mais do que simplesmente a história americana. Ela revela algo sobre a história universal. Frederick Turner lê a manifestação de diversos núcleos de povoamento, de diversas formas sociais, diversas formas de relacionamento entre civilizações mutuamente estranhas e de diferentes atividades econômicas no território americano como um registro dos diversos estágios do desenvolvimento histórico e 
social dos Estados Unidos e do mundo. O território americano é tratado por ele como o registro material que carrega em sua forma todas as etapas do desenvolvimento daquela sociedade que, em seu ponto máximo de evolução, irá produzir uma manifestação completamente nova da democracia. Tratase, na visão de Turner, de uma forma espacial que apresenta simultaneamente aquilo que a história nos apresentou de forma sucessiva. O território americano foi percebido por Turner como um material formado pelas camadas do desenvolvimento histórico sedimentado horizontalmente - de Oeste para Leste - no sentido inverso ao da ocupação e chegada dos costumes vindos da velha civilização européia. A fronteira representava, em seu esquema, o ponto inicial do estagio de desenvolvimento da sociedade que por ali agora se formava. Em The Significance of the Frontier in American History, Turner recorre às idéias de Achille Loria, um sociólogo positivista e economista italiano, que produziu entre as últimas décadas do século XIX e a primeira metade do XX. Este, segundo Turner,

"defendeu o estudo da vida colonial como ajuda para o entendimento dos estágios do desenvolvimento europeu, afirmando que o assentamento colonial é para a ciência econômica o que a montanha é para a geologia, trazendo à luz as estratificações primitivas. 'A América', diz ele, 'tem a chave para o enigma histórico que a Europa procurou, em vão, por séculos, e a terra que não tem história revela claramente o curso da historia universal'" (Turner, 1976: 11).

\section{E, para Turner,}

"Tem muita verdade nisso. Os Estados Unidos aparecem como uma imensa página na história da sociedade. Linha por linha, de Oeste para Leste, como nós lemos esta página continental, encontramos o registro da evolução social. Ela começa com o Índio e o caçador; e prossegue ao falar da desintegração da selvageria com a entrada do mercador, o desbravador da civilização; nós lemos os anais do estagio pastoril na vida dos ranchos; a exploração dos solos pelo plantio, sem rotação, do milho e do trigo nas comunidades esparsas de lavradores; a cultura intensiva dos densos assentamentos rurais; e, finalmente, a organização manufatureira com a cidade e o sistema fabril... Particularmente nos Estados do Leste, esta página é um palimpsesto. O que é agora um Estado manufatureiro foi, na década anterior, uma área de intensa agricultura. Antes ainda foi uma área de trigo e mais anteriormente foi o "campo aberto" que atraiu o vaqueiro" (Turner, 1976: 11).

Dessa forma, a partir do espetáculo proporcionado pelo avanço da fronteira -ou melhor, das diversas fronteiras-, o observador atento poderia recontar a história do território, fazendo uso de uma narrativa que segue a linearidade e encadeamento dos sucessivos fenômenos integrantes dessa dinâmica. Os diversos estágios do desenvolvimento da sociedade aparecem contados, simultaneamente, nas diversas ondas fronteiriças em contínuo avanço sobre o território americano. A configuração territorial dos Estados Unidos, para Frederick Turner, é a cristalização do processo de desenvolvimento americano, e, nesse sentido, "é [segundo Sérgio Buarque] antes uma forma de sociedade". O processo aí originado e materializado culminaria, através do embate entre a civilização e o primitivismo encontrado nas terras da fronteira, na liberdade e democracia como marcas distintivas dessa nova sociedade nascente. Cada elemento tipo contribuiu para o posicionamento da democracia no pináculo da história americana e, indiretamente, da história americana no pináculo da história universal. Mas isso somente ocorreu a partir de uma configuração territorial específica e tipicamente de fronteira.

É evidente, no entanto, que toda a historiografia brasileira pregressa dos institutos teve peso relevante na temática encampada por Sérgio, e Turner não pode, nem de longe, ser considerado a mais forte influência para o pensamento do brasileiro. O próprio Sérgio Buarque, no prefácio de Caminhos e Fronteiras, reforça essa idéia. O estudo da fronteira no continente americano, seria, segundo a própria história e conformação desses territórios, inevitável para a compreensão dessas sociedades que 
se formam no Novo Mundo. Para Sérgio Buarque de Holanda,

"A palavra 'fronteira' já surge nos textos contemporâneos da primeira fase da colonização do Brasil e bem poderia ser utilizado aqui independentemente de quaisquer relações com o significado que adquiriu na moderna historiografia, em particular na historiografia norteamericana desde os trabalhos já clássicos de Frederick Jackson Turner" (Holanda, 1994: 13).

"De qualquer modo seria injustificável a pretensão de aplicar os esquemas de Turner às condições que se criaram no Brasil e se associaram a sua expansão geográfica. O contraste entre as ações e reações dos herdeiros de um João Ramalho, por exemplo (que a si próprio se chamou, certa vez, 'fronteiro' do Paraíba), e a dos pioneers da América anglo-saxônica é, com efeito, tão obviamente radical quanto o será, sem dúvida, o que subsiste entre as conseqüências próximas ou remotas que delas podem decorrer" (Holanda, 1994: 13).

Para Henrique Manoel Silva,

"Em se tomando como verdadeiras as premissas de Turner sobre a influência e o papel exercido pela fronteira na formação do caráter americano, cujo sentido de ruptura com as antigas tradições européias e cujo alcance constitutivo da liberdade e da radicalidade democrática encontram terreno fértil, podemos talvez apontar que esses mesmos pressupostos tiveram sentido inverso na formação brasileira. Sob certos aspectos, elas serviram como modo de conservação e de reprodução das nossas estruturas oligárquicas e autoritárias, heranças das nossas tradições ibéricas" (Silva, 1999: 205).

É preciso reconhecer, nesse sentido, que "o maior problema da assimilação, por parte dos scholars brasileiros com relação à tese de Turner, é que essa, em suas prerrogativas, pretendia-se transcultural e trans-histórica, na medida em que era entendida como uma fase num processo geral de evolução. Assim o percebeu Turner, no desenvolvimento da sociedade americana" (Silva, 1999: 203). No entanto é inegável que as similitudes entre as linhas de abordagem não sejam fortuitas. "Em ambos os casos, a expansão da fronteira como fenômeno histórico foi sinônimo de guerra, travada entre civilizações, palco de etnocídios e mudanças ambientais sem precedentes históricos, sobretudo pela sua amplitude num intervalo de tempo relativamente curto" (Silva, 1999: 205).

\section{Considerações finais}

Não nos interessa aqui, contudo, reconstituir os planos de identidade e aproximação entre essas obras por elas mesmas, mas sim, apontar para o fato de que, desde a virada do século e mais expressivamente após a década de 1930, começa a se desenhar nas Américas um pensamento que se volta para a interpretação de uma dinâmica territorial comum. Esses países, que tem em comum o fato de serem ex-colônias de países europeus, encontram no movimento de avanço da fronteira um plano de identidade. O estoque de terras e a "reserva expansionista" que os países do Novo Mundo contam em seu próprio interior os colocam numa situação distinta daquela encontrada em países de formação capitalista mais antiga. A configuração espacial dessas novas sociedades será determinante para uma formação singular e radicalmente diversa daquela preconizada pelo modelo clássico da transição do feudalismo para o capitalismo. Contudo, no caso dos territórios dos países localizados na porção sul do continente americano e mais especificamente no caso brasileiro, a transição para uma sociedade plenamente capitalista não chegou sequer a se realizar por completo e, talvez, seguindo a intuição, seja possível afirmar que assim mesmo ela já terminou, revelando a verdade sobre o modelo na sua eterna incompletude. A forma dinâmica do processo e os traços de semelhança encontrados no plano da interpretação e do próprio fenômeno interessam para compreender uma dinâmica mais ampla e que, ao contrário do que declarou Mike Davis em entrevista à Folha de São Paulo, encontra continuidade na dinâmica territorial brasileira. Esse é um aspecto distintivo importante. 
Nesse sentido, as identidades de ordem mais geral não devem ocultar as profundas diferenças no que diz respeito à consolidação da democracia e de uma ordem social entendida como "moderna" que derivam da situação e da dinâmica que envolvem as terras livres no Brasil e nos Estados Unidos. O sistema oligárquico resultante da forma de uso desse imenso estoque de terras livres, que se constituiu no motor do avanço da fronteira de ocupação em território brasileiro, representa o avesso da modernização e do avanço representado pela instituição de uma ordem democrática como aquela analisada por Turner.

Se, tanto nos Estados Unidos quanto no Brasil, a fronteira representa simultaneamente, no universo das interpretações intelectuais, o encontro entre civilização e barbárie e a fonte de uma dinâmica de modernização do território (e, por essa via, da sociedade), por aqui tivemos como resultado bem marcado até hoje os aspectos que são mais ligados à barbárie. A incompletude do processo repõe na ordem do dia os elementos de violência associados à expansão da fronteira. Nesses termos, a positividade que o olhar para as especificidades da formação territorial nacional traz não pode ser da mesma natureza dos resultados obtidos pelos intelectuais norte-americanos, pelo menos daqueles que seguiram Turner. A mudança para uma matriz de pensamento de tipo situacional, tanto nos EUA quanto no Brasil, revelou, mais do que identidades, profundas diferenças que permaneciam escondidas sob o enfoque genético, negativo ou da tal "sociologia da falta".

O aspecto distintivo, no entanto, dessas abordagens consiste no esforço em recontar uma história de formação a partir da análise dos conteúdos presentes na dinâmica territorial. Mas, o fato é que, por maior que fossem os esforços acadêmicos e institucionais para uma compatibilização teórica, os elementos da dinâmica expansionista brasileira promoveram não o avanço, mas a perpetuação do atraso, segundo Martins (1999). Esse dado interferiu diretamente na produção intelectual brasileira, impedindo aí a constituição de um pensamento unitário sobre a dinâmica, a formação e a identidade continentais da América. Nesse aspecto, temos que lidar com o fato de que, se nos EUA a fronteira móvel se prestou à construção da identidade, aqui ela ainda está presente como dinâmica que impede a constituição de uma sociedade democrática e que, evidentemente, revela o outro de qualquer formação social pretendida, barrando qualquer possibilidade de geração de uma identidade única. A existência da fronteira móvel é um imperativo com o qual temos que lidar não simplesmente no campo da história, mas como um dado da geografia atual e que tem implicações diretas na vida econômica, política e social do Brasil. Essa diferença está posta, como vimos, desde o início do século $X X$. Frederick Jackson Turner conta a história de uma democracia (um tipo de democracia) já acabada enquanto que por aqui é preciso apontar para a fronteira como contenedora das forças contrárias à constituição desse princípio social.

\section{Referências bibliográficas}

ARANTES, O. Urbanismo em Fim de Linha. São Paulo: EDUSP, 1998.

ARRIGHI, G. O Longo século XX. São Paulo/Rio de Janeiro: Unesp/Contraponto, 1996.

COSTA, L. A. M. o ideário urbano paulista na virada do século. O Engenheiro Theodoro Sampaio a as questões territoriais e urbanas modernas (1886-1903). Dissertação de Mestrado. São Paulo: Faculdade de Arquitetura e Urbanismo, Universidade de São Paulo, Brasil, 2001.

CUNHA, E. À margem da história. Porto: Editora Lello Brasileira S. A., 1967.

FERREIRA, A. C. A epopéia bandeirante: letrados, instituições, invenção histórica (1870-1940). São Paulo: Editora Unesp, 2002.

FIORI, J. L. O Voo da Coruja. Rio de Janeiro: Record, 2003.

HARVEY, D. O novo imperialismo. São Paulo: Loyola, 2004. 
HOLANDA, S. B. Monções. São Paulo: Editora Brasiliense, 1990.

HOLANDA, S. B. Caminhos e Fronteiras. São Paulo: Companhia das Letras, 1994.

LENIN. Imperialismo: fase superior do capitalismo. São Paulo: Global. 1979. 127p.

LENZ, M. H. O papel de la conquista del desierto na construção do estado argentino. Ensaios FEE, 2006, vol. 27, № 2, p. 543-560.

MACHADO, L. O. Limites, fronteiras e redes. In: STROHAECKER, T. M.; DAMIANI, A.; SCHAFFER, N. O.; BAUTH, N. \& DUTRA, V. S. (orgs.). Fronteiras e Espaço Global. Porto Alegre: AGB-Porto Alegre, 1998, p. 41-49.

MARTINS, J. O poder do atraso. São Paulo: Hucitec, 1999.

MORAES, A. C. R. Bases da formação territorial do Brasil. São Paulo: Hucitec, 2000.

OLIVEIRA, A. U. A geografia da lutas no campo. São Paulo: Contexto, 1996.

ORTIZ, R. Cultura brasileira e identidade nacional. São Paulo: Brasiliense, 1985.

RANGEL, A. Inferno verde: cenas e cenários do Amazonas. Tours: Arrault, 1924.

SAMPAIO, T. Considerações Geográficas e Econômicas sobre o Vale do Rio Paranapanema. São Paulo: Comissão Geográfica e Geológica de São Paulo, Boletim No 4, 1890.

SAMPAIO, T. O Tupi na geographia nacional. São Paulo: Casa Eclética, 1901.

SCHWARCZ. L. M. O espetáculo das raças: cientistas, instituições e questão racial no Brasil - 1870-1930. São Paulo: Companhia das Letras, 1993.
SILVA, H. M. A Temática da fronteira na historiografia brasileira. Acta Scientiarum, 1999, vol. 21, No 1, p. 199-206.

SILVA, L. O. Fronteira e identidade nacional. In: ASSOCIAÇÃO BRASILEIRA DE PESQUISADORES EM HISTÓRIA ECONÔMICA (ABPHE). Anais do $V$ Congresso Brasileiro de História Econômica. Caxambú: inédito, 2003. Disponível em Internet: http://econpapers.repec.org/paper/ abphe2003/101.htm

SMITH, N. Gentrificação, a fronteira e a reestruturação do espaço urbano. Espaço e Tempo, 2007, № 21, p. 15-31.

STADNIKY, H. P. Fronteira e mito: Turner e o agrarismo norte-ameiricano. Geografia Econômica, 2007, № 7. Disponível em Inernet: http://www.CyTA.com.ar/ suplementos/gecon.htm

TURNER, F. J. The significance of the frontier in american history. In: TURNER, J. The frontier in american history. New York: Robert E. Krieger Publishing Company, 1976, p. 1-38.

VIANNA, L. W. A revolução passiva: iberismo e americanismo no Brasil. Rio de Janeiro: Editora Revan/IUPERJ, 1996.

WEGNER, R. Os Estados Unidos na obra de Sérgio Buarque de Holanda. Cadernos de Sociologia e Política, 1997, vol. 3, p. 13-25.

WEGNER, R. Sérgio Buarque de Holanda e a tese da fronteira. In: Associação Nacional de Pós-graduação e Pesquisa em Ciências Sociais (ANPOCS). Anais do XXII Encontro Anual da ANPOCS. Caxambú: ANPOCS, 1998. Disponível em Internet: http://www.fortunecity.com/meltingpot/ peacock/1000/98gt10.htm 